\title{
An Improved Energy Management Strategy For A Hybrid Fuel Cell/Battery Passenger Vessel
}

\author{
Ameen M. Bassam ${ }^{\mathrm{a}, \mathrm{b}, *}$, Alexander B. Phillips ${ }^{\mathrm{c}}$, Stephen R. Turnock ${ }^{\mathrm{a}}$, Philip A. Wilson ${ }^{\mathrm{a}}$ \\ ${ }^{a}$ Fluid Structure Interactions Group, University of Southampton, Boldrewood Innovation Campus, SO16 7QF, UK \\ ${ }^{b}$ Naval Architecture and Marine Engineering Department, Faculty of Engineering, Port Said University, Port Fouad, Egypt \\ ${ }^{c}$ National Oceanography Centre, Natural Environment Research Council, UK
}

\begin{abstract}
The combination of a fuel cell and an energy storage system for the reduction of fuel consumption and improving the dynamics of hybrid power systems has successfully been used in transportation applications. In order to realise the benefits of hybrid fuel cell power systems, an energy management strategy is essential for distributing the required power properly between the fuel cell and the energy storage system. For a hybrid fuel cell/battery passenger vessel, an improvement to the classical proportional-integral (PI) controller based energy management strategy is presented. This takes fuel cell efficiency into consideration as an input to maintain higher efficiency of fuel cell and reduce stresses on it and hence reduce its fuel consumption.

A $25.5 \mathrm{~m}$ long passenger vessel is used and its propulsion system is modelled in MATLAB/Simulink environment using the SimPowerSystems toolbox. The performance of the proposed PI energy management strategy is compared to original PI, equivalent fuel consumption minimization strategy (ECMS), and state-based energy management strategies in terms of consumed energy, battery state of charge, fuel cell efficiency, hydrogen consumption, and the stresses seen by each power source of the hybrid system taking into consideration a daily operation of 8 hours. Results indicate that a daily hydrogen saving of $3.5 \%, 1.7 \%$, and $1.4 \%$ compared to the ECMS, state-based, and the original PI strategies respectively can be achieved by adopting the proposed PI strategy in addition to lower stress on the fuel cell.
\end{abstract}

Keywords: Energy Management Strategy, Hybrid Power System, Fuel Cell, PEMFC, PI Controller.

\section{Introduction}

Much research in recent years has focused on using fuel cells in hybrid electric propulsion systems for transportation applications in order to reduce its negative environmental impacts [1]. For marine applications, hybrid electric propulsion is one of the energy efficiency design index (EEDI) related measures suggested by the International Maritime Organization (IMO) to control ship emissions 2]. Using fuel cells as a main source of power increases the potential of hybrid electric propulsion systems to reduce energy demand and pollution [3, 4].

Among the various fuel cell technologies available, proton exchange membrane fuel cell (PEMFC) is considered the most promising because of its solid electrolyte, high efficiency even at low loads, low operating temperature, quick start-up, high power density, low noise, and zero emission [5, 6]. However, PEMFC has a time-delayed response, therefore an energy storage system is normally used with the fuel cell in a hybrid power system [7, 8. Hybridizing fuel cells with an energy storage system can improve the dynamics and efficiency of the power system,

\footnotetext{
* Corresponding author

Email address: ab2e12@soton.ac.uk (Ameen M. Bassam )
}

lower its size, and reduce its cost. Moreover, since part of the load will be provided by the energy storage system, fuel cell performance can be optimized specially during rapid load changes [8, 9]. This optimization is achieved through an energy management strategy (EMS).

For hybrid fuel cell propulsion systems, the proper split of the required power between the fuel cell system and the energy storage system is a challenging problem which requires the design of an EMS. This EMS will control the dynamic behaviour of the hybrid power system components which affects the system efficiency, fuel consumption and lifetime. Therefore, developing a suitable EMS for hybrid fuel cell propulsion system has been a very important research topic [7, 8, 10]. The objectives of an EMS include reducing hydrogen consumption, increasing the fuel cell efficiency, reducing the size and weight of the power system, reducing the operation cost, reducing the stress on the power system components to prolong its working lifetime [11, 12, 13. EMS objectives also include reducing emissions, maintaining the battery state of charge (SOC) or the bus voltage at a certain level [10, 14].

Most of the work reported in the literature on EMS tends to focus on the automotive industry applications; however, several studies have been made on developing EMS for marine applications. A state-based EMS has been 
developed in 15 for a passenger vessel equipped with a fuel cell/battery hybrid power system with the main objective of maximizing the system efficiency. For the same vessel, a fuel cell/battery/ultra-capacitor hybrid power system with a fuzzy logic EMS has been proposed in [16] to further enhance the performance of the hybrid system. A hybrid fuel cell/battery system was developed for a $20 \mathrm{~m}$ long tourist boat in Korea with a total power of about 90 $\mathrm{kW}$. The developed EMS for this boat aims to provide the required power using mainly the fuel cell system in a loadfollowing mode and discharge the battery power whenever the required power is higher than the fuel cell system available power [17]. For underwater vehicles and small ships, an EMS has been developed which requires the fuel cell to provide an average power demand, while the energy storage system is discharged or recharged when the required power is higher or lower the average power demand supplied by the fuel cell [12, 18.

The aim of this work is to improve the classical proportional-integral (PI) controller based EMS for a hybrid fuel cell/battery passenger vessel. This improvement includes taking fuel cell efficiency into consideration as an input to the PI EMS in order to maintain high efficiency of the fuel cell and better performance which helps in reducing its fuel consumption, reducing stress on it, reducing its maintenance and replacement costs, and extending its lifetime. The performance of the proposed PI EMS is compared with that from three alternative strategies: the original PI EMS, the state-based EMS developed in 15 for the same vessel and the equivalent fuel consumption minimization strategy (ECMS) which gives a near-optimal performance. For a full mission profile of 8 hours, the performance comparison is carried out in terms of the consumed energy, battery SOC, fuel cell efficiency and hydrogen consumption. The criteria for performance comparison includes as well the stress on each power source measured using Haar wavelet transform. These stresses impact on the lifetime of the hybrid power system components.

The paper is organized as follows. Section 2 describes the examined vessel and its propulsion system. Section 3 outlines the implementation of the four energy management strategies. Section 4 shows the simulation results and validation. Finally, the work conclusions are presented in Section 5.

\section{Vessel \& Voyage Description}

This study uses the world's first hydrogen fuel cell passenger vessel 'FCS Alsterwasser' as a case study. This vessel was developed as part of the ZEMSHIPS project funded by the EU-Life program [19. A hydrogen filling station has been built by Linde Group as a part of this project. FCS Alsterwasser operates around Hamburg, Germany on Lake Alster, HafenCity, the River Elbe and the inner city waterways for round and charter trips [19]. This vessel has been classified by the Germanischer Lloyd and its main particulars are shown in Table 1 .

\begin{tabular}{l|l} 
Table 1: Specifications of the FCS Alsterwasser passenger vessel \\
\hline Capacity & 100 passengers \\
Length & $25.5 \mathrm{~m}$ \\
Breadth & $5.36 \mathrm{~m}$ \\
Depth & $2.65 \mathrm{~m}$ \\
Draft & $1.33 \mathrm{~m}$ \\
Displacement & 72 tonnes \\
Top speed & $8 \mathrm{kn}$ \\
Powering & $2 \mathrm{PEMFC} \mathrm{of} 48 \mathrm{~kW}$ each \\
& $360 \mathrm{Ah} / 560 \mathrm{~V}$ lead-gel battery \\
\hline
\end{tabular}

FCS Alsterwasser is equipped with two PEMFC with a peak power of $48 \mathrm{~kW}$ each, which have proven to be an extremely reliable energy source connected to the DC bus using a DC-DC converter to control the voltage. A 360 Ah battery is also connected directly to the DC bus to power a $100 \mathrm{~kW}$ electric motor as shown in Figure 1. The vessel is also equipped with twelve hydrogen tanks at a pressure of 350 bar and a hydrogen weight of $50 \mathrm{~kg}$ which is sufficient for two or three days of operation without refuelling [17. The required time for filling the hydrogen tanks is about twelve minutes [20].

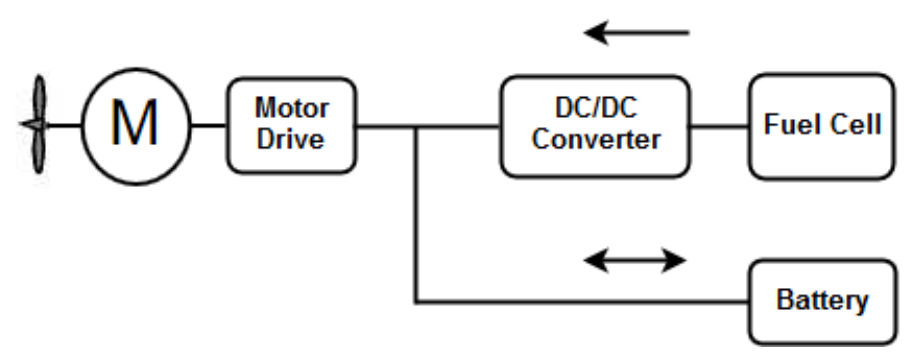

Figure 1: Configuration of the vessel fuel cell/battery hybrid propulsion system

An extract of the power requirements for a typical voyage on the Alster, Hamburg, Germany has been measured and published in [19, 15. This power requirement includes propulsion and auxiliary power. The data measured from [15] shown in Figure 2 starts with a cruising time of about 90 seconds, the vessel then enters a docking phase lasting 45 seconds. The vessel is alongside for 25 seconds. Finally the vessel starts to sail again and reaches its cruising speed after an acceleration time of about 35 seconds, giving 300 seconds total time for the manoeuvre.

Based on the typical power consumption shown in Figure 2, the power consumption of a complete voyage from Finkenwerder to Landungsbrucken has been extrapolated as shown in Figure 3. Duration of the full journey is about 1 hour as shown in Table 2 with 4 stops between the two destinations as shown in Figure 4 [21.

In order to cover a daily vessel operation of 8 hours, the developed load power requirement shown in Figure 3 


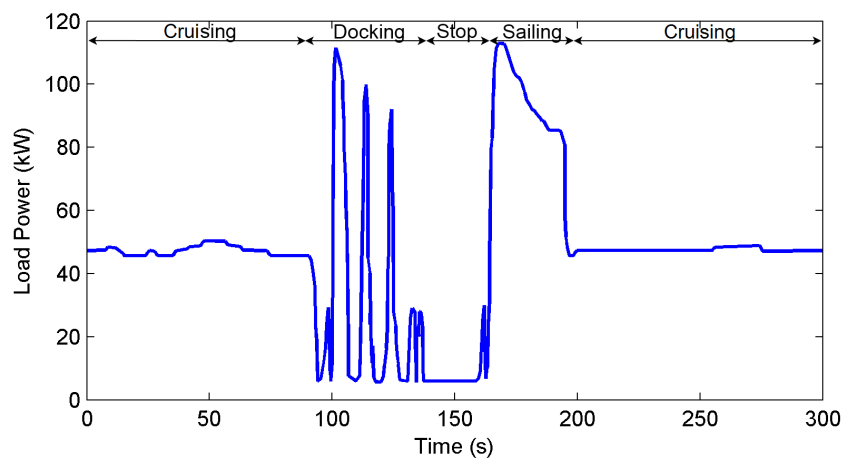

Figure 2: Part of the real typical load characteristics on the Alster

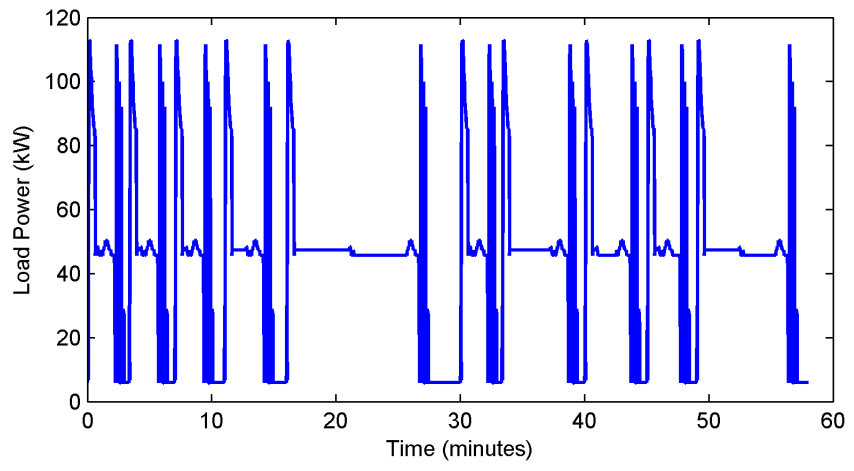

Figure 3: Developed power requirement of a real full voyage between Finkenwerder and Landungsbrucken has been repeated for 8 times in order to be used as an input to the simulation of the EMS as will be described in the following sections.

\section{Energy Management Strategy}

\subsection{State-based EMS}

State-based control is one of the deterministic rulebased methods used to control each component of the hybrid system for different transportation applications. This kind of strategy can have many operating states to decide the operating points of the fuel cell and battery systems according to the required power and the battery SOC taking into consideration the operational limits of the hybrid system components 22, 23.

For the same vessel 'FCS Alsterwasser', a state-based EMS was developed in [15] to determine the proper split

Table 2: Finkenwerder - Landungsbrucken time table 21

\begin{tabular}{|c|c|c|c|}
\hline Landungsbrucken & 19.15 & Finkenwerder & 19.45 \\
Altona & 19.18 & Bubendey-Ufer & 19.48 \\
Dockland & 19.22 & Neumuhlen & 19.55 \\
Neumuhlen & 19.26 & Dockland & 20.00 \\
Bubendey-Ufer & 19.31 & Altona & 20.04 \\
Finkenwerder & 19.43 & Landungsbrucken & 20.13 \\
\hline
\end{tabular}

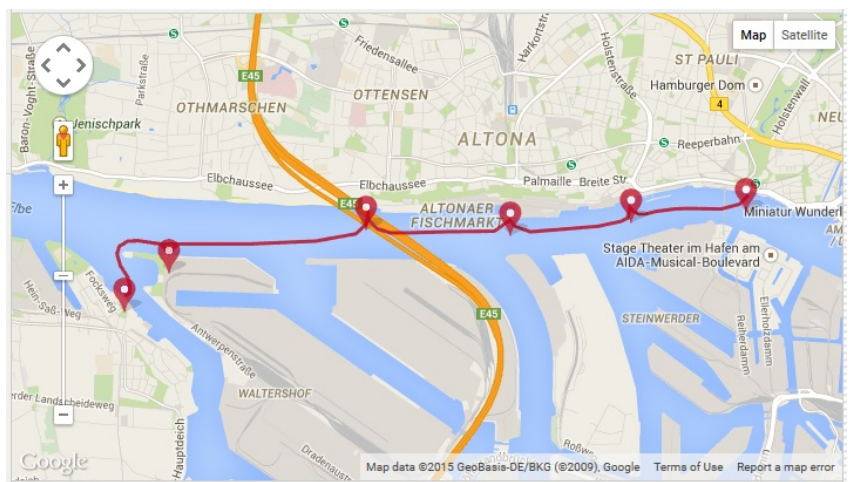

Figure 4: The examined vessel route 21]

of the required power between the components of the hybrid fuel cell/battery system with an objective of maximizing the system efficiency. This strategy consists of 11 states for 11 possible cases of combination between battery SOC, required load power $\left(P_{\text {load }}\right)$, fuel cell minimum power $\left(P_{\mathrm{FCmin}}\right)$, optimum fuel cell power $\left(P_{\mathrm{FCopt}}\right)$, maximum fuel cell power $\left(P_{\mathrm{FCmax}}\right)$, battery optimum discharge power $\left(P_{\text {optdis }}\right)$, battery optimum charge power $\left(P_{\text {optchar }}\right)$ and battery optimum power $\left(P_{\text {BATopt }}\right)$ as shown in Table 3.

The value used for the battery optimum charge is equal to optimum discharge power with $30 \%$ battery capacity while battery optimum power equates to $20 \%$ battery capacity as suggested in [15. Fuel cell minimum, optimum, and maximum power values are selected based on the current and voltage limits of the fuel cell in order to maximize the system efficiency which is the main objective of this EMS. The main inputs of this EMS are the required load power and the battery SOC which are used to decide the fuel cell power. Then, the difference between the required load power and the fuel cell power is used to charge or discharge the battery.

In this EMS, as can be seen in Table 3 , fuel cells operate at minimum power when the battery SOC is normal or high and the required load power is not too high as in states 1, 2, and 5. During high required load power or low battery SOC, fuel cells operate at its maximum power as in states 4,9 and 11 to provide the required load power and charge the battery. Meanwhile fuel cells are regulated to follow the load power in states $3,6,8$ and 10 and it works at its optimum power value in state 7 only.

\subsection{Original \& Proposed PI EMS}

Recently, EMS based on classical PI and PID controllers have been proposed due to their simplicity, these can be easily tuned for the examined mission profile. The main goal of original PI EMS is to maintain the battery SOC at its nominal value in order to reduce the stress on it and extend its lifetime [9, 10. In the original PI EMS, the current battery SOC is compared to a reference value of battery SOC (SOC_Ref) to control the battery power or 
Table 3: Summary of a state-based EMS 15

\begin{tabular}{l|c|c|c}
\hline Battery SOC & State & Load Power & Fuel cell reference power \\
\hline SOC $>80 \%$ & 1 & $P_{\text {load }} \leq P_{\mathrm{FCmin}}$ & $P_{\mathrm{FCmin}}$ \\
& 2 & $P_{\text {load }} \leq P_{\mathrm{FCmin}}+P_{\text {optdis }}$ & $P_{\mathrm{FCmin}}$ \\
& 3 & $P_{\text {load }} \leq P_{\mathrm{FCmax}}+P_{\text {optdis }}$ & $P_{\mathrm{FC}}=P_{\text {load }}-P_{\text {optdis }}$ \\
& 4 & $P_{\mathrm{FCmax}}+P_{\text {optdis }}<P_{\text {load }}$ & $P_{\mathrm{FCmax}}$ \\
\hline $50 \% \leq \mathrm{SOC} \leq 80 \%$ & 5 & $P_{\text {load }} \leq P_{\mathrm{FCmin}}$ & $P_{\mathrm{FCmin}}$ \\
& 6 & $P_{\text {load }} \leq P_{\mathrm{FCopt}}-P_{\mathrm{BATopt}}$ & $P_{\text {load }}$ \\
& 7 & $P_{\text {load }} \leq P_{\mathrm{FCopt}}+P_{\mathrm{BATopt}}$ & $P_{\mathrm{FCopt}}$ \\
& 8 & $P_{\text {load }} \leq P_{\mathrm{FCmax}}$ & $P_{\text {load }}$ \\
& 9 & $P_{\text {load }}>P_{\mathrm{FCmax}}$ & $P_{\mathrm{FCmax}}$ \\
\hline SOC $<50 \%$ & 10 & $P_{\text {load }} \leq P_{\mathrm{FCmax}}-P_{\text {optchar }}$ & $P_{\text {load }}+P_{\mathrm{optchar}}$ \\
& 11 & $P_{\text {load }}>P_{\mathrm{FCmax}}-P_{\text {optchar }}$ & $P_{\mathrm{FCmax}}$ \\
\hline
\end{tabular}

current using PI controller as shown in Figure 5. This battery power is subtracted from the load power to calculate the fuel cell power. Then, the battery and fuel cell power are divided by the voltage to calculate the current drained from the fuel cell and battery. By discharging/charging the battery, battery SOC will change and will be fed back to the EMS block to close the loop of the PI controller.

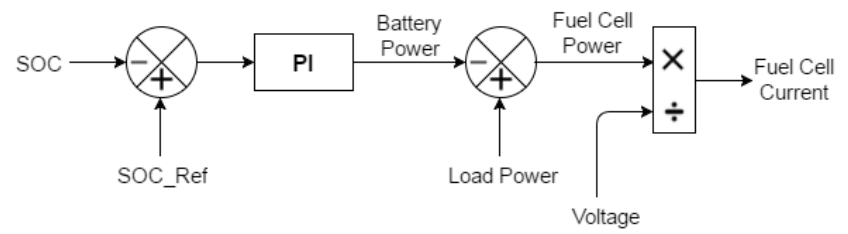

Figure 5: Original PI control energy management strategy scheme 9

The inputs of this EMS are the battery SOC and the required load power with an ultimate goal of maintaining the battery SOC around its reference value which makes the fuel cell follow the required load power or operate at its maximum power when the current battery SOC drops below its reference value. This effects the fuel cell efficiency, hydrogen consumption and lifetime. Therefore, a proposed PI EMS is developed in this paper that takes fuel cell efficiency into account as an input to the EMS. By avoiding the operation of fuel cells in a poor efficiency region, its fuel consumption can be reduced. Furthermore, its operational stresses can be lowered that allows the reduction of fuel cell maintenance cost and extending its lifetime.

In the proposed PI EMS, fuel cell efficiency (FC_Eff) is taken into consideration by comparing it to a reference value (FC_Eff_Ref) in order to control the fuel cell current which is removed from the required load current to obtain the battery current. Then, the battery current is updated according to the difference between the current battery SOC and its reference value as shown in Figure 6 ensuring that the power requirement is completely satisfied. By consuming power from the battery and fuel cell, battery SOC and fuel cell efficiency will change and fed back to the EMS to close the loops of the PI controllers.

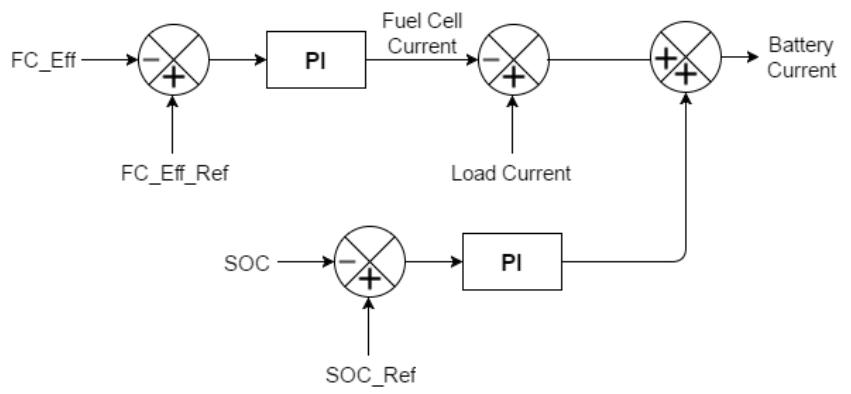

Figure 6: Proposed PI control energy management strategy scheme

PI controllers can be reliably used for the proposed PI EMS, since fuel cell efficiency is linear with the fuel cell current for approximately $80 \%$ of load currents after an initial non-linearity region at low loads as shown in Figure 15 which can be neglected 24. Moreover, using fuel cell efficiency as an input allows the fuel cell to operate more at higher efficiency which means reduced hydrogen consumption, less stress and longer lifetime. Moreover, the proposed PI EMS maintains the required battery SOC which is the main objective of the original PI EMS. The gains of the PI controllers of the original and the proposed PI strategies are manually tuned for the examined driving cycle with the help of the MATLAB control system toolbox in order to have balance between the controller performance and robustness 25.

\subsection{Equivalent fuel consumption minimization strategy}

One of the most common real-time optimization control methods is the ECMS which generates a near-optimal solution of the required power split problem. ECMS does not require a priori knowledge of the future power requirement and its concept is to minimize the instantaneous fuel consumption of the hybrid system 9, 26. This concept was proposed in 27] to develop an instantaneous optimization EMS for hybrid vehicles. The equivalent fuel consumption $(C)$ includes the actual fuel cell hydrogen consumption $\left(C_{\mathrm{FC}}\right)$ as well as the equivalent consumption $244210 \mathrm{f}$ the battery storage system $\left(C_{\mathrm{Batt}}\right)$. The optimization 
problem to minimize the hydrogen consumption can be defined as follows:

$$
P_{\mathrm{FCopt}}=\stackrel{\operatorname{argmin} C}{P_{\mathrm{FCopt}}}=\frac{\operatorname{argmin}\left(C_{\mathrm{FC}}+\alpha \cdot C_{\mathrm{Batt}}\right)}{P_{\mathrm{FCopt}}}
$$

where $(\alpha)$ is a penalty coefficient which is used to accomplish the charge-sustaining operation of the battery. It is calculated as a function of battery SOC limits as follows:

$$
\alpha=1-2 \mu \frac{\left(\mathrm{SOC}-0.5\left(\mathrm{SOC}_{\mathrm{H}}+\mathrm{SOC}_{\mathrm{L}}\right)\right)}{\mathrm{SOC}_{\mathrm{H}}-\mathrm{SOC}_{\mathrm{L}}}
$$

where $\left(\mathrm{SOC}_{\mathrm{H}}\right)$ and $\left(\mathrm{SOC}_{\mathrm{L}}\right)$ are the upper and lower limit of the battery SOC respectively. Meanwhile, $\mu$ is the SOC constant which is used to reflect the characteristics of the battery charge/discharge process 28 . As shown in Figure 7, based on the load power and the battery SOC, the fuel cell power is decided. This fuel cell power is subtracted from the load power to calculate the battery power. Then, fuel cell and battery powers are divided by voltage to calculate the value of current.

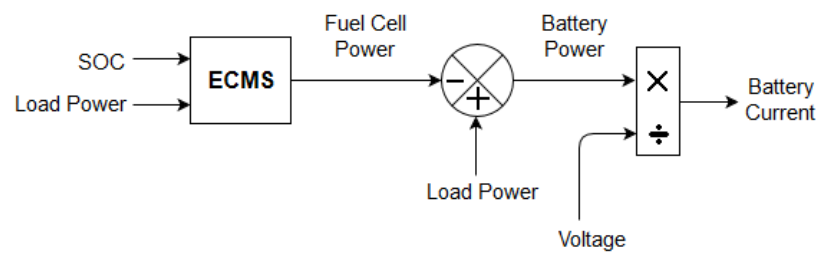

Figure 7: Equivalent fuel consumption minimization strategy scheme

In the next section, the components of the hybrid fuel cell/battery system of the examined passenger vessel is implemented in MATLAB/Simulink environment using the SimPowerSystems (SPS) toolbox. Also, the proposed PI EMS is implemented in Simulink as well as the original PI, ECMS, and the original state-based EMS which was developed for the examined ship in 15 to compare its performance in terms of the consumed energy, battery state of charge (SOC), fuel cell efficiency and hydrogen consumption.

\section{Simulation Implementation and Results}

The vessel fuel cell/battery hybrid system illustrated in Figure 1 is modelled mathematically in MATLAB/Simulink environment in order to study and understand the behaviour of different energy management strategies which allows the design of the EMS effectively. As shown in Figure 8, the EMS subsystem converts the load required power into current and splits it between the fuel cell and the battery subsystems according to the used EMS. The modelling approach of each subsystem is described in this section.

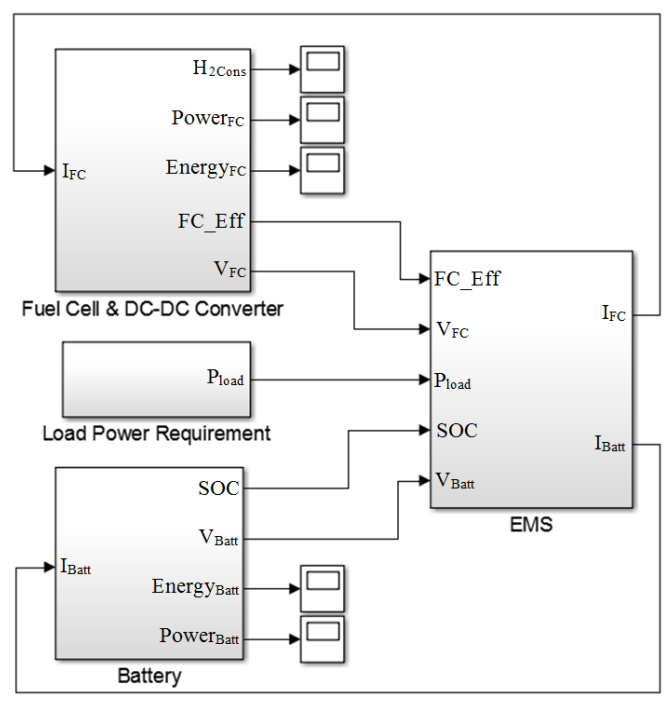

Figure 8: Hybrid fuel cell/battery power system in Simulink/MATLAB environment

\subsection{Fuel cell \& DC-DC converter subsystem \\ 4.1.1. Fuel cell}

Due to its advantages, PEMFC has been used and studied for different applications including portable, transportation and stationery applications. Modelling of PEMFC has attracted attention and many performance models of PEMFC have been developed. A generic model of a PEMFC developed and validated in 29 is selected in this study. This model is implemented in Simulink as shown in Figure 9 and integrated in SPS library of electrical power systems as a generic hydrogen fuel cell stack model.

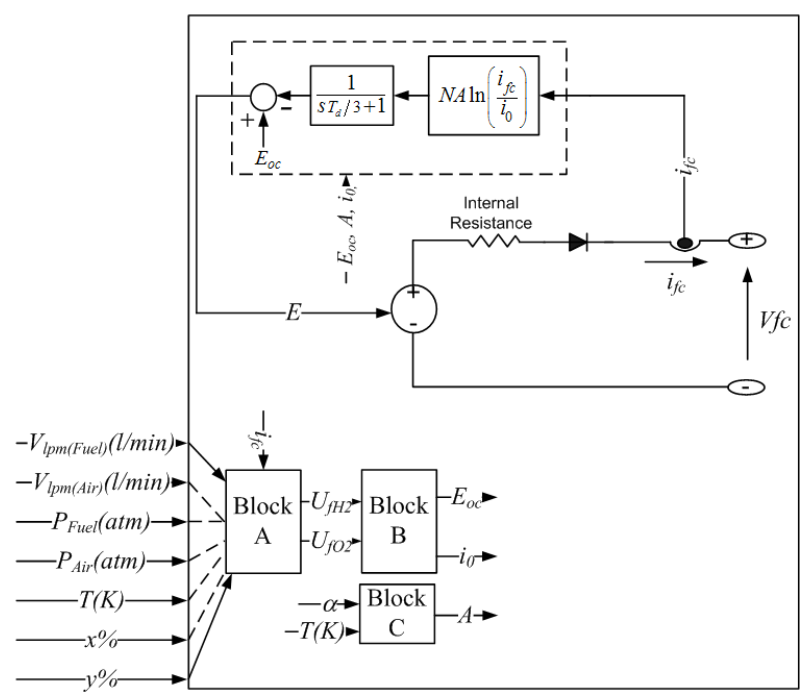

Figure 9: Fuel cell model in Simulink/MATLAB environment adapted from 30.

The main parameters of this model can be obtained from the fuel cell datasheet or from its polarization curve test which makes this model easy to use. This model can 
represent both steady-state and dynamic performance of PEMFC taking fuel cell response time into consideration. Moreover, this model considers the features of electrical and chemical models. This model has been validated with experimental data as well as datasheet performance data with an error of $\pm 1 \%$. More details on this model can be found in 29. The hydrogen consumption of PEMFC $\left(\mathrm{H}_{2 \mathrm{Cons}}\right)$ can be calculated as follows 9 :

$$
\mathrm{H}_{2 \text { Cons }}=\frac{\mathrm{N}}{\mathrm{F}} \int \mathrm{I}_{\mathrm{FCnet}} \cdot d t
$$

where $(\mathrm{N})$ is the number of cells, $(\mathrm{F})$ is the Faraday constant and $\left(\mathrm{I}_{\mathrm{FCnet}}\right)$ is the net current drained from the PEMFC. Then, this hydrogen consumption is used to calculate the hydrogen cost and energy input to the PEMFC as follows:

$$
\text { Energy }_{\mathrm{FC}}=\mathrm{H}_{2 \mathrm{Cons}} \times \mathrm{HHV}_{\mathrm{H}_{2}}
$$

where $\left(\mathrm{HHV}_{\mathrm{H}_{2}}\right)$ is the higher heating value of the hydrogen fed to the PEMFC.

\subsection{2. $D C$ - $D C$ converter}

The voltage of the hybrid system components varies according to the demanded current from each power source. Therefore, an electronic circuit is needed to stabilise the power source voltage while providing the required power. In order to regulate the output voltage of the PEMFC, a boost type unidirectional DC-DC converter is used between the fuel cell system and the DC bus as shown in Figure 1 for the examined vessel [15]. The used converter is composed of an inductor $\mathrm{L}$, a switch $\mathrm{S}$ and a diode $\mathrm{D}$ as shown in Figure 10. The net current supplied by the PEMFC into the DC bus through this DC-DC converter is readjusted according to the operating voltage ratio $(\mathrm{k})$ 31 as follows:

$$
\begin{aligned}
& \mathrm{k}=\mathrm{V}_{\mathrm{Batt}} / \mathrm{V}_{\mathrm{FC}} \\
& \mathrm{I}_{\mathrm{FCnet}}=\mathrm{I}_{\mathrm{FC}} \times \mathrm{k}
\end{aligned}
$$

where $\left(\mathrm{V}_{\text {Batt }}\right)$ is the battery voltage, $\left(\mathrm{V}_{\mathrm{FC}}\right)$ is the fuel cell voltage and $\left(\mathrm{I}_{\mathrm{FC}}\right)$ is the required current from the fuel cell/DC-DC converter subsystem.

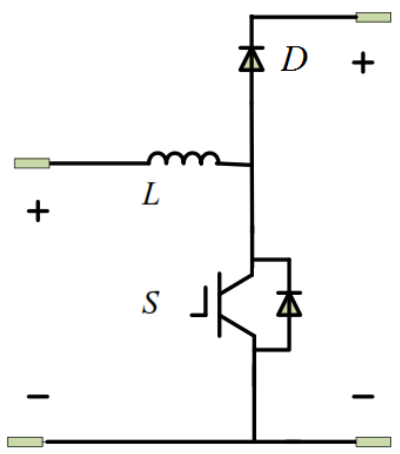

Figure 10: Electrical scheme of the fuel cell boost DC-DC converter 15
For this study, a preset Simulink PEMFC model is used with a nominal power of $50 \mathrm{~kW}$ and maximum power of $120 \mathrm{~kW}$ which is sufficient to provide the average load required power shown in Figure 2, The fuel cell model nominal efficiency is $55 \%$. It is assumed to be fed with hydrogen and air and its resistance is constant. A DC-DC converter is used to connect the fuel cell to the DC bus according to Equation 5 assuming a constant efficiency of the converter to be $95 \% 32$.

\subsection{Battery subsystem}

Because batteries are considered the main energy storage device for transportation applications, modelling of batteries receives much attention. The SPS library includes an improved easy-to-use dynamic battery model that can represent both steady state and dynamic behaviour of the battery taking into account the response time of the battery. Therefore it is used in this study.

The generic battery block can simulate four types of battery which are: lead acid, lithium-ion, nickel-cadmium or nickel-metal-hydride. The battery model has been validated against experimental results for the 4 different battery types with a maximum error of $5 \%$ however error increase to $\pm 10 \%$ when battery state of charge (SOC) decreases below 20\% 33 however it is not recommended to fully discharge a battery. Figure 11 shows the equivalent circuit of the used battery model [30].

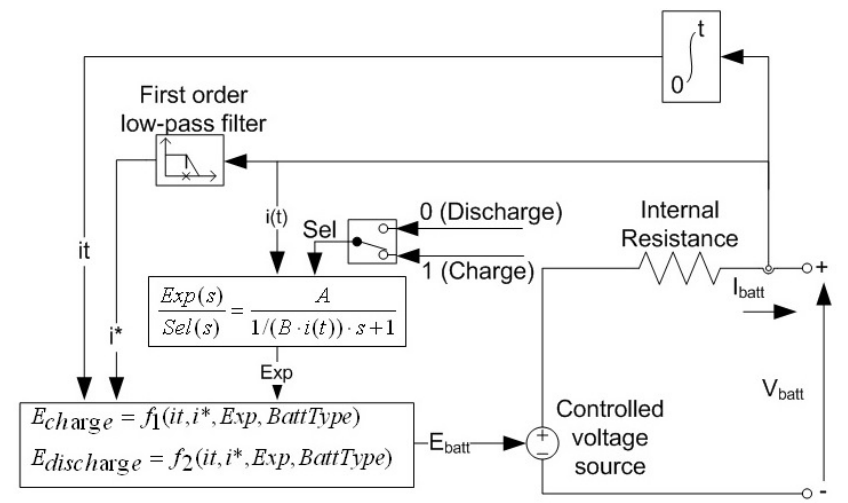

Figure 11: Battery model in Simulink/MATLAB environment adapted from 30]

Battery voltage $\left(\mathrm{V}_{\text {Batt }}\right)$ is calculated as a function of open circuit voltage $\left(\mathrm{E}_{\text {batt }}\right)$, internal resistance $\left(\mathrm{R}_{\mathrm{ohm}}\right)$ and battery current $\left(\mathrm{I}_{\text {Batt }}\right)$ as follows:

$$
\mathrm{V}_{\text {Batt }}=\mathrm{E}_{\text {batt }}-\mathrm{R}_{\mathrm{ohm}} \cdot \mathrm{I}_{\text {Batt }}
$$

where $\left(\mathrm{E}_{\text {batt }}\right)$ depends on battery type as discussed in 33 . The drained power and energy from the battery can be calculated as follows:

$$
\begin{aligned}
& \text { power }_{\text {Batt }}=\mathrm{V}_{\text {Batt }} \times \mathrm{I}_{\text {Batt }} \\
& \text { Energy }_{\text {Batt }}=\int \text { power }_{\text {Batt }} . d t
\end{aligned}
$$

For this study, the examined vessel is equipped with a 360 Ah lead-gel battery which is a lead-acid battery type 
with a voltage of $560 \mathrm{~V}$ 19 which is modelled using this battery model and used in this study 33 .

\subsection{EMS subsystem}

The state-based EMS, ECMS, original PI EMS, and the proposed PI EMS are mathematically modelled and implemented in the simulation environment to make a performance comparison in terms of fuel cell hydrogen consumption and efficiency, battery SOC, total consumed energy, and stresses seen by each power source. The comparison is made for a full driving cycle of 8 hours developed based on the available real typical load requirements shown in Figure 3 .

The inputs of the EMS subsystem includes the required load power, fuel cell voltage and efficiency, and battery voltage and SOC. The main outputs of the EMS subsystem are the required current which will be drained of the battery and fuel cell subsystems as shown in Figure 8. Also, the EMS subsystem includes a first-order delay loop as suggested in 34 for the examined strategies in order to limit the changing rate of the required power from the fuel cell subsystem which will reduce the stress on the fuel cell and increase its lifetime.

Before comparing different energy management strategies, the results of the EMS subsystem for the state-based EMS is validated against the published results in [15] as shown in Figures 12 to 14 . The hybrid fuel cell/battery system shown in Figure 1 is implemented in Simulink environment using the mathematical models of PEMFC (50 $\mathrm{kW}$ nominal power) and battery (lead-acid, $360 \mathrm{Ah}, 560 \mathrm{~V}$, $65 \%$ initial SOC) as described previously. The load profile shown in Figure 2 is used as an input to the state-based EMS subsystem as suggested in 15. The state-based EMS splits the required load power between the fuel cell in Figure 12 and the battery in Figure 13 while Figure 14 shows battery SOC.

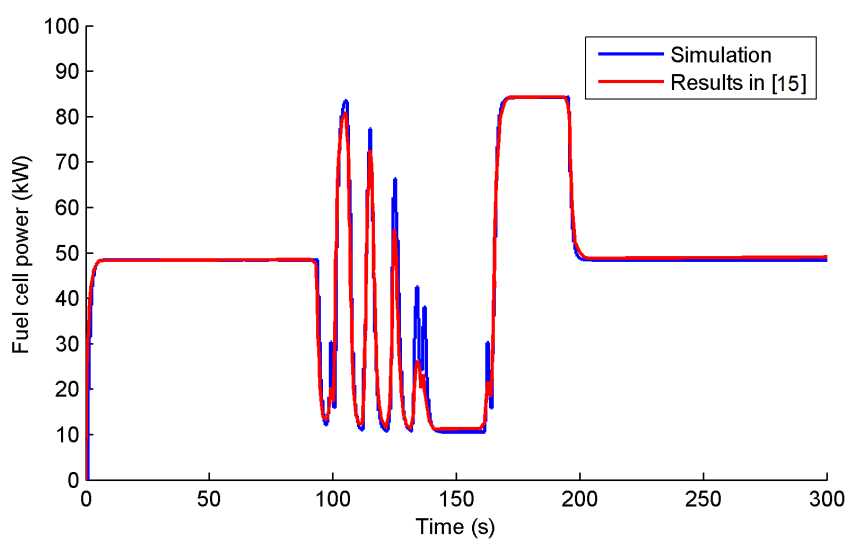

Figure 12: Validation of fuel cell power using the state-based strategy

Figures 12 to 14 show good agreement between the

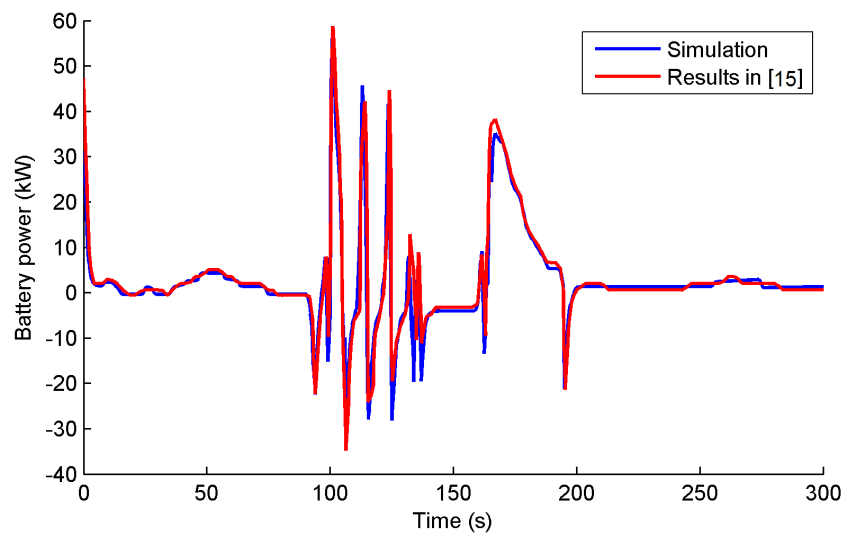

Figure 13: Validation of battery power using the state-based strategy

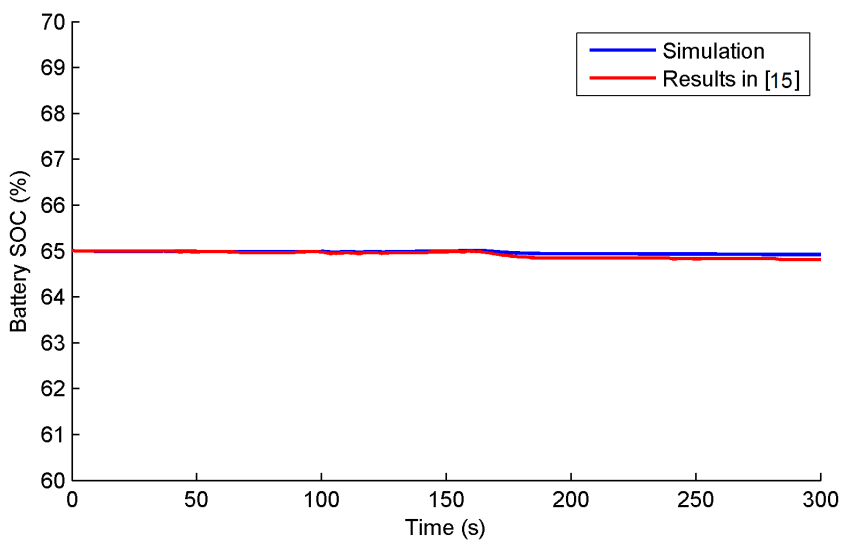

Figure 14: Validation of battery SOC using the state-based strategy

\subsection{Results}

In this subsection, the proposed PI EMS is compared with the original PI EMS, ECMS, and the state-based EMS which has been developed in [15] for the same examined vessel. To compare different energy management strategies appropriately, the same PEMFC and battery models with the same initial conditions are used where a normal battery SOC of $65 \%$ is chosen as an initial condition for the examined strategies.

For the original and proposed PI EMS simulation, reference values of the battery SOC and fuel cell efficiency should be selected carefully. The nominal efficiency of the used PEMFC model is $55 \% 29$ which can increase at part loads 32 as shown in Figure 15. Therefore, a higher fuel cell efficiency than $55 \%$ is selected as a reference value of fuel cell efficiency for the proposed PI EMS which is $60 \%$.

A nominal battery SOC of $60 \%$ is chosen as a battery SOC reference value for the original and proposed PI EMS as recommended by automotive industry designers [10]. The P and I gains of the battery SOC PI controllers are 50000 and 1 for the original PI EMS and 200 and 0.0001 for the proposed PI EMS respectively. For the ECMS and the state-based EMS, $\mathrm{SOC}_{\mathrm{H}}$ and $\mathrm{SOC}_{\mathrm{L}}$ are set to $80 \%$ and $50 \%$ as suggested in [15, 35] in order to prolong the battery life. The SOC constant $\mu$ is set to 0.6 to balance 


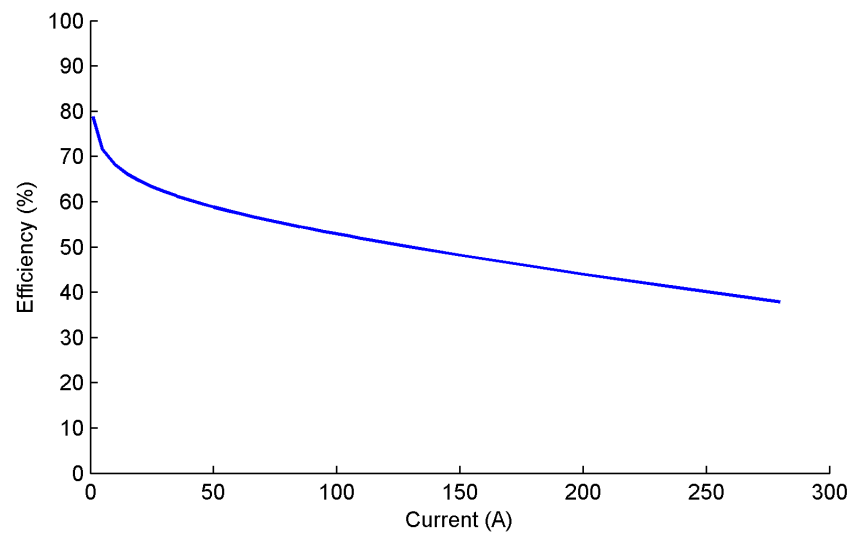

Figure 15: Fuel cell stack efficiency versus current

the battery SOC during the examined driving cycle using the ECMS as reported in 9, 26, 28.

In order to have a closer look on how each EMS splits the required load power between the fuel cell and the battery, the same load profile shown in Figure 2 is considered. As shown in Figures 16 and 17, the state-based EMS regulates the fuel cell to follow the load power because the battery SOC is normal. At high loads during docking and acceleration phases, the battery begins to work. Meanwhile at low loads, the fuel cell works at its minimum power and starts to charge the battery.

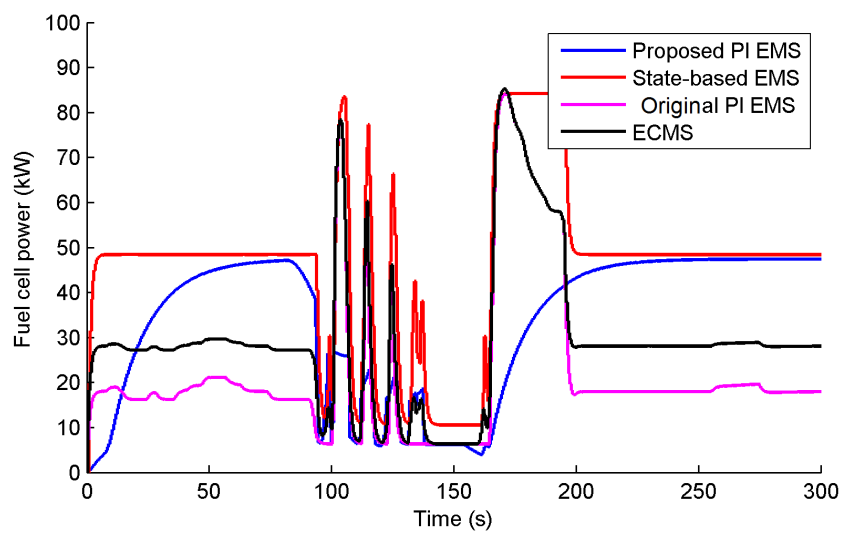

Figure 16: Comparison of fuel cell power using different strategies

By adopting the original PI EMS whose main objective is to maintain battery SOC at its reference value, the battery starts to discharge faster to get to the battery SOC reference value as shown in Figure 18 while the fuel cell works at its minimum power and gives more power during high load phases. Because ECMS transforms the battery electrical energy consumption into an equivalent hydrogen consumption, it doesn't deplete the battery as fast as the original PI EMS.

In the state-based EMS and the original PI EMS, the fuel cell mostly follows the load power or works at its minimum power which affects its efficiency and fuel consumption. Therefore, in the proposed PI EMS fuel cell efficiency

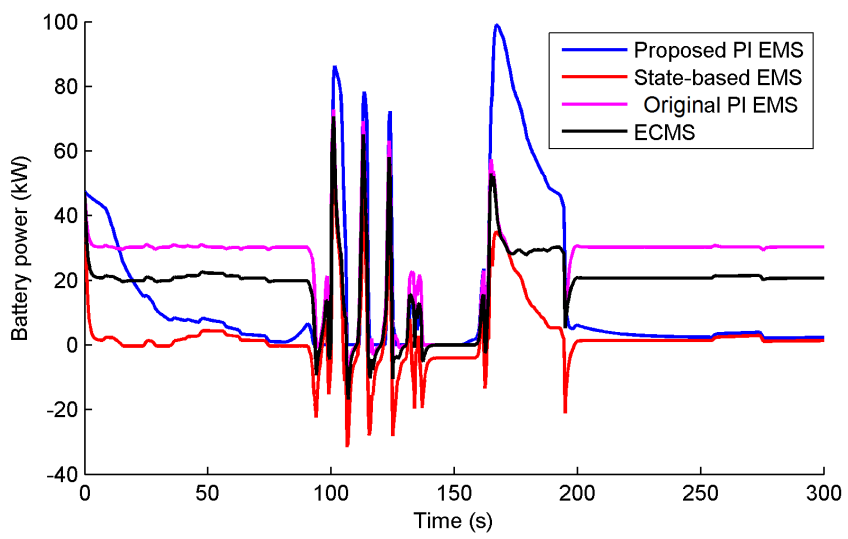

Figure 17: Comparison of battery power using different strategies

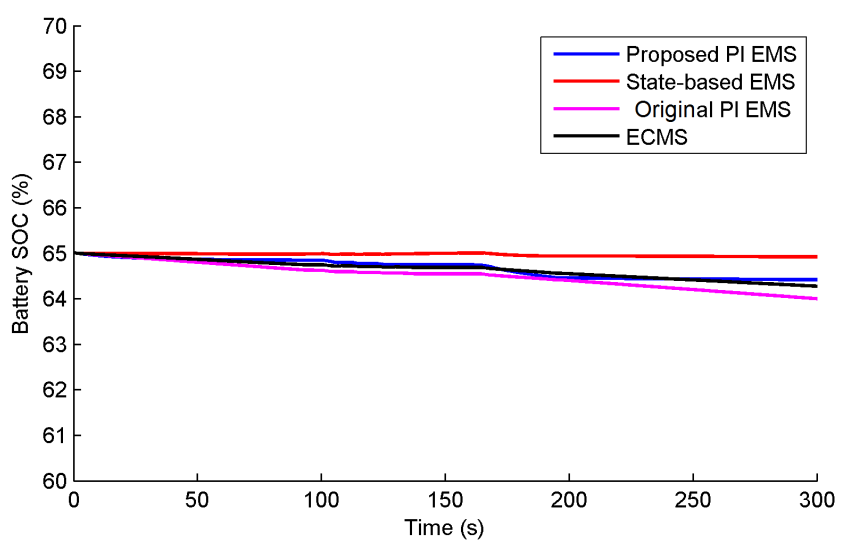

Figure 18: Comparison of battery SOC using different strategies

is taken into consideration as an input which results in the fuel cell spending more time at its optimum power. This also reduces the fluctuations in required load as shown in Figure 16. However, to have a better indication about the performance of each EMS and its effect on the battery SOC, fuel cell efficiency and hydrogen consumption, a longer load profile should be considered.

For a full working cycle of 8 hours, simulation results show that, the hybrid fuel cell/battery system consumes less hydrogen using the proposed PI EMS than the ECMS by $3.4 \%$ and by $1.6 \%$ using the state-based EMS and by $1.4 \%$ using the original PI EMS.

One reason for this saving in hydrogen consumption is taking fuel cell efficiency into consideration as an input to the EMS as proposed in this study which maintains the fuel cell efficiency around $55 \%$ or higher in the case of adopting the proposed PI EMS while fuel cell efficiency can be lower than $50 \%$ using the state-based EMS or original PI EMS as illustrated in Figure 19

To compare fuel cell stack efficiency during the 8 hours driving cycle for the four different strategies, the mean, standard deviation (SD) and coefficient of variation of fuel cell efficiency are calculated. As listed in Table 4 the average value of fuel cell efficiency is similar for the four examined EMS. However, the SD and coefficient of vari- 


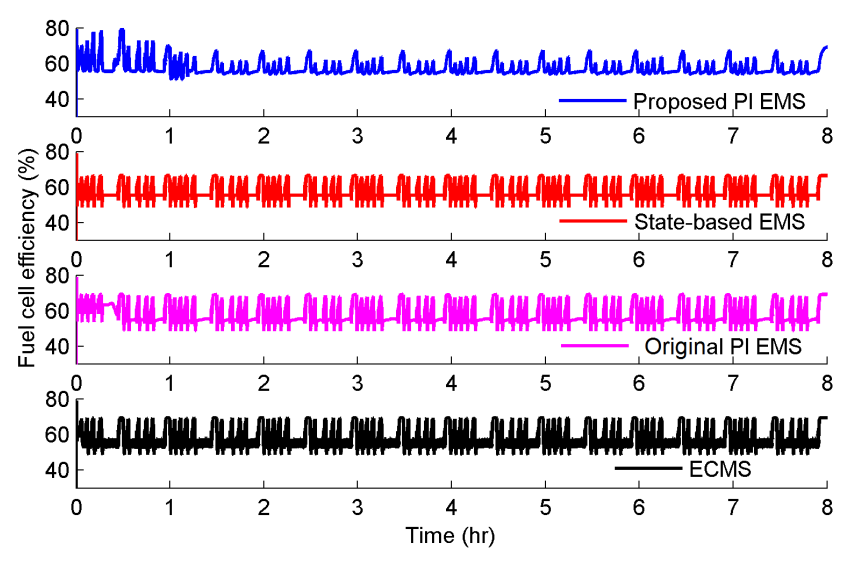

Figure 19: Fuel cell stack efficiency during the examined voyage using different strategies ance of the proposed PI EMS are significantly lower by $9 \%$ and $12.5 \%$ respectively compared to the state-based EMS, $25 \%$ and $30 \%$ respectively compared to the original PI EMS, and 30\% and 30\% respectively compared to the ECMS strategy. This means less variability and high stability of fuel cell efficiency during the examined load cycle 36] which means less stress on the fuel cell stack and results in longer lifetime and saving in hydrogen consumption.

Table 4: Mean, standard deviation, and coefficient of variation of fuel cell stack efficiency comparison using different strategies

\begin{tabular}{l|l|l|l}
\hline & Mean (\%) & SD (\%) & $\begin{array}{l}\text { Coefficient } \\
\text { of variation }\end{array}$ \\
\hline Proposed PI EMS & 57.2 & 4.2 & 0.07 \\
State-based EMS & 57.4 & 4.6 & 0.08 \\
Original PI EMS & 57.8 & 5.6 & 0.10 \\
ECMS & 57.9 & 6 & 0.10 \\
\hline
\end{tabular}

Another reason for the hydrogen consumption saving achieved by the proposed PI EMS is that the proposed PI EMS tends to use more power from the battery than the state-based EMS, the original PI EMS, and the ECMS as shown in Figure 22. The battery discharges faster in the case of the original PI EMS than the proposed PI EMS because the main objective of the original PI EMS is to maintain the battery SOC at its reference value as shown in Figure 20. However, in the case of the state-based EMS, the battery discharges more gradually which results in a higher final battery SOC of the state-based EMS. Meanwhile, ECMS maintains the battery SOC around $64 \%$ which is approximately the average value of $\mathrm{SOC}_{\mathrm{H}}$ and $\mathrm{SOC}_{\mathrm{L}}$. Figures 21 and 22 illustrate the fuel cell and battery power during the examined voyage using different strategies.

\subsubsection{Sensitivity analysis}

In order to study the effect of the selected reference value of fuel cell efficiency on the performance of the proposed PI EMS, a sensitivity analysis is performed. Differ-

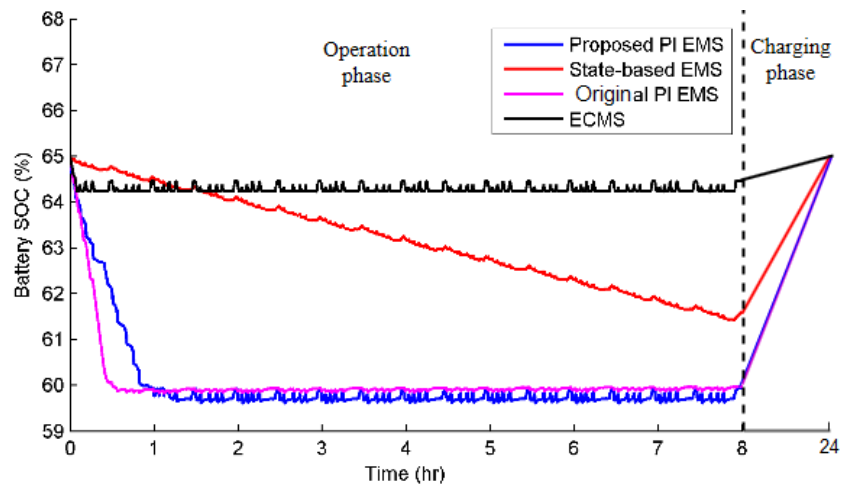

Figure 20: Battery SOC during the examined voyage using different strategies

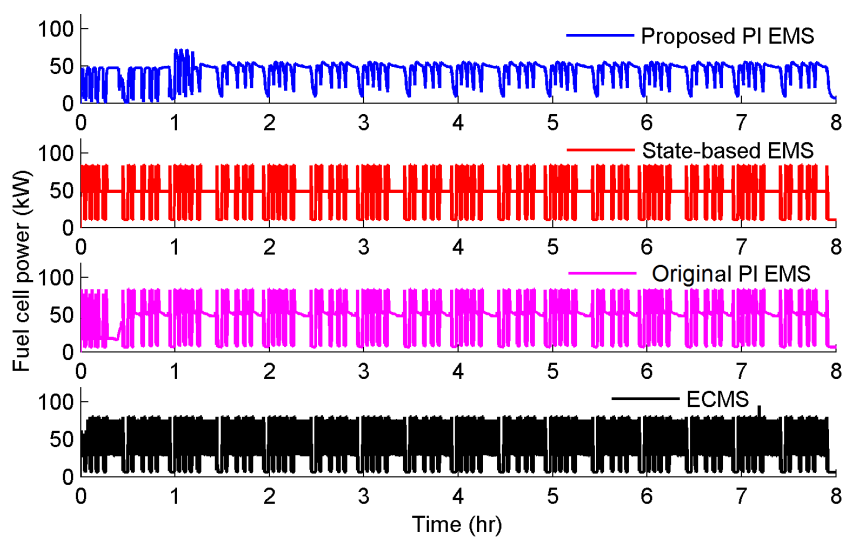

Figure 21: Fuel cell power during the examined voyage using different strategies

ent values of fuel cell efficiency are used as reference values for the proposed PI EMS to calculate the hydrogen consumption saving percentage using the proposed PI EMS compared to other strategies for the examined 8 hours of operation as shown in Figure 23

As shown in Figure 23, fuel cell efficiency reference value starts from the fuel cell stack nominal efficiency of $55 \%$. By increasing the fuel cell efficiency reference value, the hydrogen consumption saving percentage increases until $65 \%$ where it starts to level off. This levelling off is expected because higher fuel cell efficiency is achieved in the low load region as shown in Figure 15 where it is difficult to operate because of the vessel required power and the fuel cell and battery operational limits. Therefore, the optimum reference value of fuel cell efficiency for the proposed PI EMS that gives the lowest hydrogen consumption is $65 \%$ for the examined full driving cycle of 8 hours. The hydrogen consumption saving percentages of the proposed PI EMS using the optimum reference value of fuel cell efficiency of $65 \%$ are $3.5 \%, 1.7 \%$, and $1.4 \%$ compared to the ECMS, state-based, and the original PI strategies respectively. 


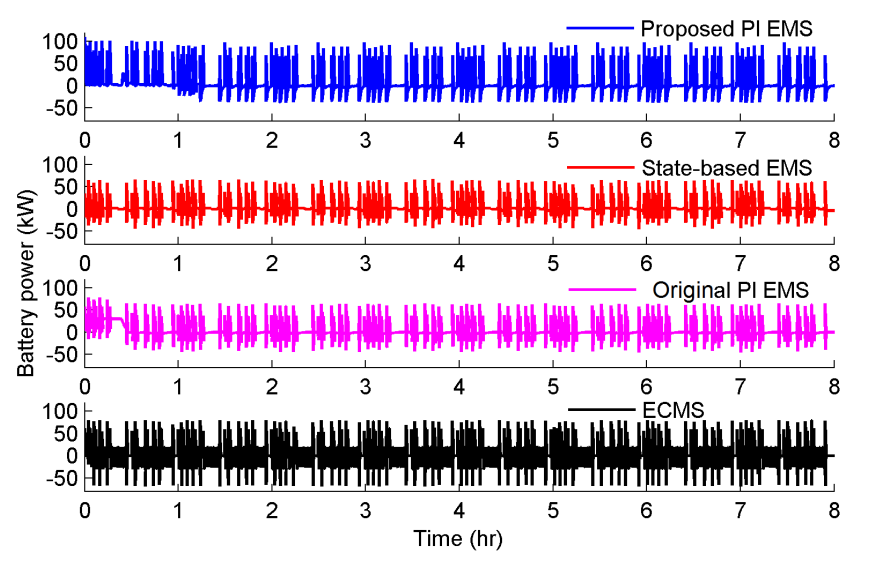

Figure 22: Battery power during the examined voyage using different strategies

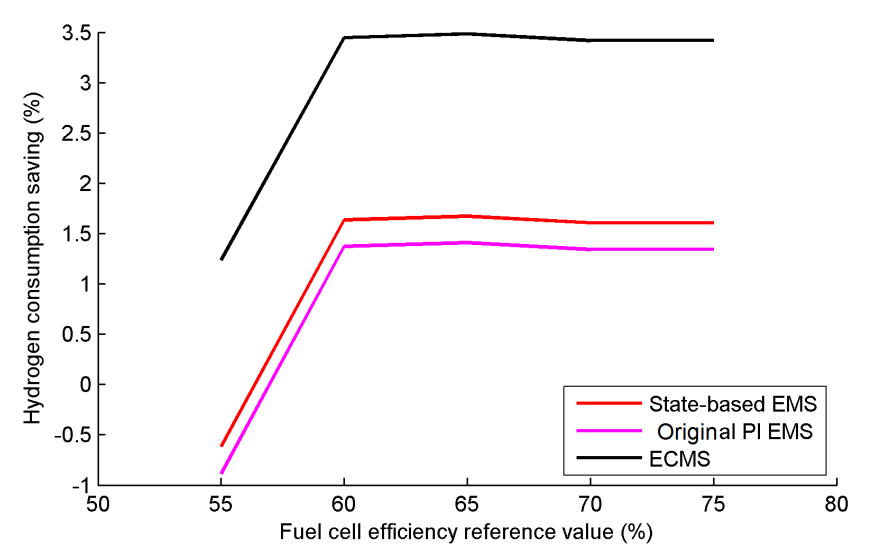

Figure 23: Fuel cell efficiency reference values effect on the hydrogen consumption saving percentage of the proposed PI strategy

\subsubsection{Stress analysis}

The lifetime of the hybrid fuel cell/battery system, reliability and durability depend mainly on the intended application and the stress on each power source of the hybrid system. Since fuel cells have shorter life and higher maintenance and replacement costs compared to batteries, more focus is now on extending the lifetime of fuel cells [37, 38. Reducing fuel cell operational stresses can significantly help in extending its lifetime and reducing its fuel consumption. Therefore, it is proposed to take fuel cell efficiency into consideration by the EMS in order to avoid operating the fuel cell away from high efficiency region.

The approach suggested in 9 to determine the stress on the fuel cell and the battery is used in this study. This approach uses Haar wavelet transform to decompose the instantaneous power from the fuel cell and battery into approximation coefficients which contains the low frequency components of the power and detail coefficients which contain the high frequency components 39. The standard deviation of the high frequency components can give a good indication of the stress on each power source of the hybrid fuel cell/battery system for the examined mission profile. As shown in Table 5 , the proposed PI EMS has the low- est fuel cell stress while it has higher battery stress than other strategies as a result of the trade-off issue between the stresses on the fuel cell and the battery. Moreover, the proposed PI EMS has the lowest hydrogen consumption and more use of the battery energy. An overall performance comparison of the proposed PI EMS is presented in Table 5 using the optimum reference value of the fuel cell efficiency of $65 \%$ for the proposed PI EMS as discussed earlier.

\subsubsection{Total energy \& cost analysis}

In order to have a fair comparison between different strategies, the total cost and total consumed energy during the 8 hours period of operation should be calculated and compared. The total cost includes hydrogen cost and the cost of charging the battery back to its initial SOC assuming charging efficiency of $88 \%$ [40]. In this study, hydrogen cost is assumed to be $4.823 \$ / \mathrm{kg}$ and the battery energy cost is assumed to be $0.284 \$ / \mathrm{kWh}$ using shore-shared (or shore-side) energy 41. The total energy is calculated as a function of the consumed power from the fuel cell from (4) and the battery depleted energy from (7) during the examined voyage.

Figure 24 shows that adopting the proposed PI EMS results in an energy saving of $3.4 \%$ compared to the ECMS. However, it consumes more energy than the state-based EMS and the original PI strategies by $3.1 \%$ and $2.7 \%$ respectively for the examined 8 hours of operation. Moreover, adopting the proposed PI EMS results in a cost saving of $3.3 \%$ compared to the ECMS as well but its operating cost is higher than the state-based EMS and the original PI strategies by $10 \%$ and $8.7 \%$ respectively at the end of the examined 8 hours of operation as shown in Figure 25.

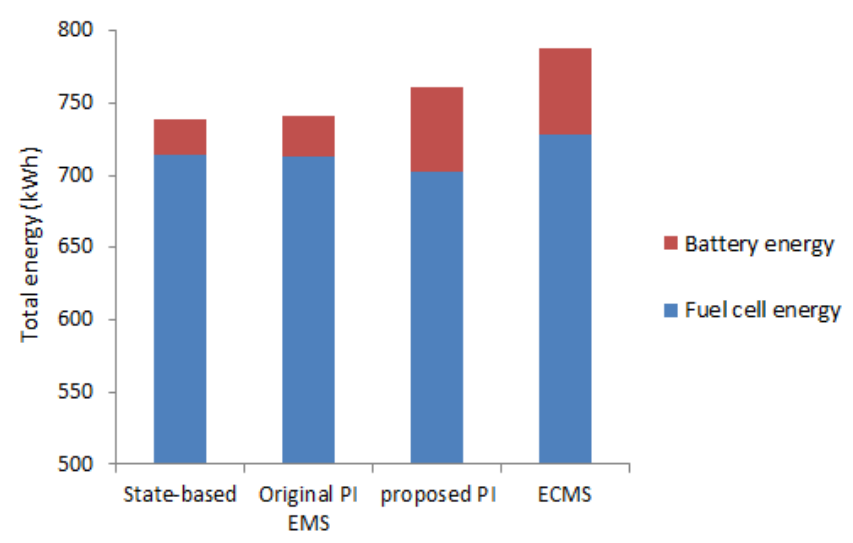

Figure 24: Comparison of total consumed energy during the examined voyage using different strategies

The reported cost saving percentages is calculated according to the assumed prices of hydrogen and electricity however, these prices varies temporally and spatially. Therefore, an energy price ratio $(\beta)$ is used to study the effect of changing energy price on the operating cost saving, 
Table 5: Overall performance comparison

\begin{tabular}{|c|c|c|c|c|}
\hline & Proposed PI EMS & State-based EMS & Original PI EMS & ECMS \\
\hline Fuel cell stress & 19.94 & 29.1 & 32.29 & 36.54 \\
\hline Battery stress & 32.81 & 13.03 & 15.24 & 26.53 \\
\hline Hydrogen consumption (kg) & 17.83 & 18.13 & 18.08 & 18.47 \\
\hline Battery SOC (\%) & $65-59.95$ & $65-61.6$ & $65-59.97$ & $65-64.24$ \\
\hline
\end{tabular}

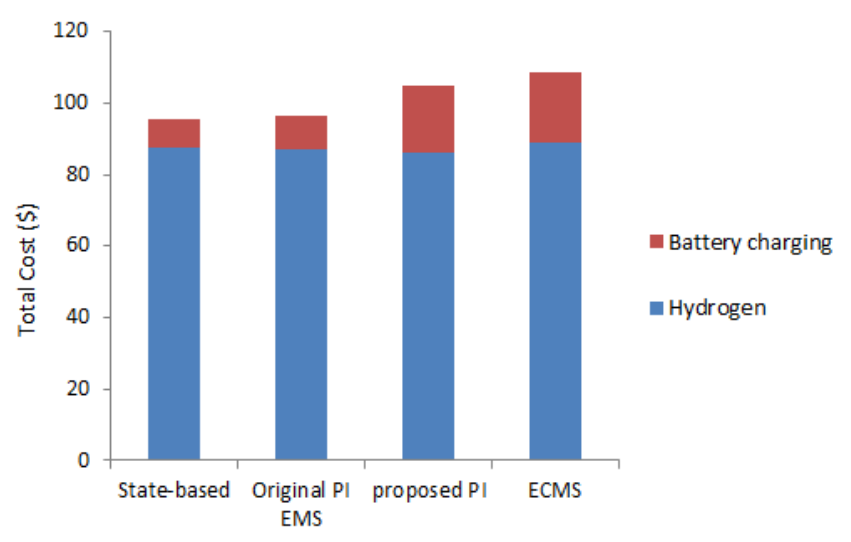

Figure 25: Comparison of total operating cost of the examined voyage using different strategies

it can be defines as follows.

$$
\beta=\frac{\text { Price of Hydrogen per } \mathrm{kWh}}{\text { Price of Electricity per } \mathrm{kWh}}
$$

centages of the proposed PI EMS compared to the statebased EMS and the original PI EMS become higher for higher values of $\beta$ meanwhile the operating cost saving percentage of the proposed PI EMS compared to the ECMS doesn't change noticeably for higher values of $\beta$. This can be justified by the fact that the state-based and the original PI strategies tend to use less battery energy therefore it is more affected by changing hydrogen price and $\beta$.

\section{Conclusion}

The design of green ships has generated significant recent research interest in order to comply with the more stringent environmental regulations. Without these regulations, $\mathrm{CO}_{2}$ emissions may increase by up to $250 \%$ by 2050 according to the last IMO study. Therefore, using fuel cells in hybrid electric propulsion systems are attracting widespread interest because of its advantages of high efficiency, low emission and quiet operation. The efficiency and performance of fuel cell hybrid systems depend considerably on the used energy management strategy which is responsible for splitting the required power between the different components of the hybrid system.

In this paper, we first propose an improved PI energy management strategy for marine applications that takes fuel cell efficiency into consideration as an input. The proposed strategy has been studied for the first fuel cell passenger vessel showing better performance than the statebased strategy developed for the same vessel as well as the original PI and ECMS strategies in terms of hydrogen consumption and fuel cell stresses with no additional first cost or hardware changes. For a full driving cycle of 8 hours, a performance comparison has been made in terms of total consumed energy, total cost, battery state of charge, fuel cell efficiency, hydrogen consumption, and the stress seen by each power source. Simulation results show that a daily hydrogen saving of $3.5 \%, 1.7 \%$, and $1.4 \%$ compared to the ECMS, state-based, and the original PI strategies respectively can be achieved by adopting the proposed PI strategy. Also, the proposed strategy has lower energy and operational cost than the ECMS strategy but it has higher energy and operational cost than the state-based and original PI strategies. Moreover, taking fuel cell efficiency into consideration as an input to the energy management strategy as proposed in this study has contributed in better fuel cell performance during operation and less stress on the fuel cell stack which prolongs its lifetime and resulted in less hydrogen consumption.

As can be seen in Figure 26, operating cost saving per- 


\section{Acknowledgement}

This research is funded by the Egyptian Government.

\section{References}

[1] R. K. Ahluwalia, X. Wang, Fuel cell systems for transportation: status and trends, Journal of power sources 177 (2008) 167-176.

[2] E. K. Dedes, D. A. Hudson, S. R. Turnock, Assessing the potential of hybrid energy technology to reduce exhaust emissions from global shipping, Energy Policy 40 (2012) 204-218.

[3] Z. Bazari, T. Longva, Assessment of IMO mandated energy efficiency measures for international shipping, International Maritime Organization (2011).

[4] M. C. Díaz-de Baldasano, F. J. Mateos, L. R. Núñez-Rivas, T. J. Leo, Conceptual design of offshore platform supply vessel based on hybrid diesel generator-fuel cell power plant, Applied Energy 116 (2014) 91-100.

[5] J. T. Pukrushpan, A. G. Stefanopoulou, H. Peng, Control of fuel cell breathing, Control Systems, IEEE 24 (2004) 30-46.

[6] Y. Wang, K. S. Chen, J. Mishler, S. C. Cho, X. C. Adroher, A review of polymer electrolyte membrane fuel cells: technology, applications, and needs on fundamental research, Applied Energy 88 (2011) 981-1007.

[7] J. Torreglosa, P. Garcia, L. Fernandez, F. Jurado, Predictive control for the energy management of a fuel-cell -battery -supercapacitor tramway, IEEE Transactions on Industrial Informatics 10 (2014) 276-285.

[8] L. Xu, M. Ouyang, J. Li, F. Yang, L. Lu, J. Hua, Optimal sizing of plug-in fuel cell electric vehicles using models of vehicle performance and system cost, Applied Energy 103 (2013) 477487.

[9] S. N. Motapon, L.-A. Dessaint, K. Al-Haddad, A comparative study of energy management schemes for a fuel-cell hybrid emergency power system of more-electric aircraft, IEEE Transactions on Industrial Electronics 61 (2014) 1320-1334.

[10] A. Fadel, B. Zhou, Power management methodologies for fuel cell-battery hybrid vehicles, Technical Report, SAE Technical Paper, 2010.

[11] L. Xu, M. Ouyang, J. Li, F. Yang, L. Lu, J. Hua, Application of pontryagin's minimal principle to the energy management strategy of plugin fuel cell electric vehicles, International Journal of Hydrogen Energy 38 (2013) $10104-10115$.

[12] Q. Cai, D. Brett, D. Browning, N. Brandon, A sizing-design methodology for hybrid fuel cell power systems and its application to an unmanned underwater vehicle, Journal of Power Sources 195 (2010) 6559-6569.

[13] I. Valero, S. Bacha, E. Rulliere, Comparison of energy management controls for fuel cell applications, Journal of power sources 156 (2006) 50-56.

[14] P. Thounthong, S. Ral, B. Davat, Energy management of fuel cell/battery/supercapacitor hybrid power source for vehicle applications, Journal of Power Sources 193 (2009) $376-385$.

[15] J. Han, J.-F. Charpentier, T. Tang, An energy management system of a fuel cell/battery hybrid boat, Energies 7 (2014) 2799-2820.

[16] L. Zhu, J. Han, D. Peng, T. Wang, T. Tang, J.-F. Charpentier, Fuzzy logic based energy management strategy for a fuel cell/battery/ultra-capacitor hybrid ship, in: International Conference on Green Energy, IEEE, 2014, pp. 107-112.

[17] C. H. Choi, S. Yu, I.-S. Han, B.-K. Kho, D.-G. Kang, H. Y. Lee, M.-S. Seo, J.-W. Kong, G. Kim, J.-W. Ahn, S.-K. Park, D.-W Jang, J. H. Lee, M. Kim, Development and demonstration of PEM fuel-cell-battery hybrid system for propulsion of tourist boat, International Journal of Hydrogen Energy 41 (2016) 3591 -3599 .

[18] N.-C. Shih, B.-J. Weng, J.-Y. Lee, Y.-C. Hsiao, Development of a $20 \mathrm{kw}$ generic hybrid fuel cell power system for small ships and underwater vehicles, International Journal of Hydrogen Energy 39 (2014) 13894-13901.
[19] C. Thimm, Zemships - the first fuel cell passenger ship in hamburg, in: ZERO REGIO Workshop, Montecatini Terme, Italy, 2007.

[20] J. J. de Troya, C. lvarez, C. Fernndez-Garrido, L. Carral, Analysing the possibilities of using fuel cells in ships, International Journal of Hydrogen Energy 41 (2016) 2853 - 2866.

[21] HADAG, http://www.hadag.de/english/harbour-ferries. html 2015. Accessed: 2015-09-04.

[22] S. F. Tie, C. W. Tan, A review of energy sources and energy management system in electric vehicles, Renewable and Sustainable Energy Reviews 20 (2013) 82 - 102.

[23] P. Garcia, L. M. Fernandez, C. A. Garcia, F. Jurado, Energy management system of fuel-cell-battery hybrid tramway, Industrial Electronics, IEEE Transactions on 57 (2010) 4013-4023.

[24] W. Choi, J. Howze, P. Enjeti, Development of an equivalent circuit model of a fuel cell to evaluate the effects of inverter ripple current, Journal of Power Sources 158 (2006) 1324 1332

[25] MATLAB control system toolbox, http://uk.mathworks.com/ products/control/ 2016. Accessed: 2016-07-18.

[26] L. Xu, J. Li, J. Hua, X. Li, M. Ouyang, Optimal vehicle control strategy of a fuel cell/battery hybrid city bus, International Journal of Hydrogen Energy 34 (2009) 7323 - 7333.

[27] G. Paganelli, S. Delprat, T. M. Guerra, J. Rimaux, J. J. Santin, Equivalent consumption minimization strategy for parallel hybrid powertrains, in: Vehicular Technology Conference, 2002. VTC Spring 2002. IEEE 55th, volume 4, 2002, pp. 2076-2081 vol.4. doi 10.1109/VTC.2002.1002989.

[28] L. Xu, J. Li, J. Hua, X. Li, M. Ouyang, Adaptive supervisory control strategy of a fuel cell/battery-powered city bus, Journal of Power Sources 194 (2009) 360-368.

[29] S. Njoya, O. Tremblay, L.-A. Dessaint, A generic fuel cell model for the simulation of fuel cell vehicles, in: Vehicle Power and Propulsion Conference, 2009. VPPC'09. IEEE, IEEE, 2009, pp. $1722-1729$.

[30] Mathworks, http://uk.mathworks.com/help/, 2015. Accessed: 2015-08-30.

[31] L. Barelli, G. Bidini, A. Ottaviano, Optimization of a PEMFC/battery pack power system for a bus application, Applied energy 97 (2012) 777-784.

[32] Fuel Cell Handbook (Seventh Edition), Technical Report, EG \& G Technical Services, Inc., 2004. Contract No.DE-AM2699FT40575.

33] O. Tremblay, L.-A. Dessaint, Experimental validation of a battery dynamic model for EV applications, World Electric Vehicle Journal 3 (2009) 1-10.

[34] M. Ouyang, L. Xu, J. Li, L. Lu, D. Gao, Q. Xie, Performance comparison of two fuel cell hybrid buses with different powertrain and energy management strategies, Journal of Power Sources 163 (2006) 467-479.

35] P. Garcia, J. Torreglosa, L. Fernndez, F. Jurado, Viability study of a fc-battery-sc tramway controlled by equivalent consumption minimization strategy, International Journal of Hydrogen Energy 37 (2012) 9368 - 9382.

[36] D. Tilman, C. L. Lehman, C. E. Bristow, Diversity-stability relationships: statistical inevitability or ecological consequence?, The American Naturalist 151 (1998) 277-282.

37] C.-H. Chao, J.-J. Shieh, A new control strategy for hybrid fuel cell-battery power systems with improved efficiency, International Journal of Hydrogen Energy 37 (2012) 13141 - 13146. 12th CHEC.

[38] J. Zhuo, C. Chakrabarti, K. Lee, N. Chang, S. Vrudhula, Maximizing the lifetime of embedded systems powered by fuel cellbattery hybrids, IEEE Transactions on Very Large Scale Integration (VLSI) Systems 17 (2009) 22-32.

[39] S. Lahmiri, Wavelet low- and high-frequency components as features for predicting stock prices with backpropagation neural networks, Journal of King Saud University - Computer and Information Sciences 26 (2014) $218-227$.

[40] A. Foley, B. Tyther, P. Calnan, B. . Gallachir, Impacts of electric vehicle charging under electricity market operations, Ap- 
plied Energy 101 (2013) 93 - 102. Sustainable Development of Energy, Water and Environment Systems.

[41] R. Winkel, U. Weddige, D. Johnsen, V. Hoen, G. Papaefthymiou, Potential for Shore Side Electricity in Europe, Technical Report, ECOFYS Consultancy, 2015. Project number:TRANL14441. 